aurium, and it occurred to me that since a large number of persons have noises in the head-say one-half the entire adult population-it is probable that, when listening intently, a considerable number of observers heard the sounds of their own ears only. This is especially true of "sizzling," "hissing," and "buzzing" sounds.

If physicians affected with tinnitus are not careful to exclude the noises propagated in their own heads, they may discover many curious physical signs in the chests of their patients in making auscultatory examinations. SAMUEL SEXTON

12, West Thirty-fifth Street, New York, October 12

\section{The Red Spot on Jupiter}

ON October 24 , at $17 \mathrm{~h} .32 \mathrm{~m}$., this object was estimated exactly central on the planet. As seen with my ro-inch reflector, power 252, the spot was very plain, though the low altitude of Jupiter rendered the telescopic image far from good.

My impression is that this red spot is now decidedly more conspicuous than it was when I last saw it on July 8, and that during the ensuing opposition it will again attract general observation as one of the most prominent features of Jovian detail. This well-known marking has now been watched for more than seven years, and its present aspect leads to the inference that its existence will be indefinitely prolonged. We may therefore justly regard it as a lineament of singular permanency. Though its motion and appearance (i.e. (int) have been subject to considerable variation, there has been little, if any change in either the shape or size of the spot. The mystery regarding its origin and real nature may perhaps ultimately be revealed on the basis of renewed and more exact observation in future years.

W. F. DENNING

Bristol, October 25

\section{A Remarkable Sunset}

WHILE out for a walk this afternoon I was struck by a pecu. liarity in the sunset which 1 do not remember to have seen noticed before. The sun set about $4.43 \mathrm{p} . \mathrm{m}$., and there was the usual "after-glow." I began to notice this first about five o'clock; there was then in the west a large bank of cumulus cloud rather low down, above this was a brilliant lemon-yellow, very bright, and this was bounded by a broad arc of a pale pink, the latter fading away into the light blue of the sky. Very soon afterwards I noticed that the pink arc, instead of being continuous, was really made up of a series of beams of bright light, which pointed to the position of the sun. I counted these, and made out five bright rays at unequal distarces apart; behind this (as it seemed) there were a few yellow cirrus clouds. A sunset like this I have often noticed before, but what followed is, I think, novel. The bright rays were slowly turning round like the spokes of a huge wheel moving in a direction contrary to the hands of a watch. I noticed also that the breadth between the bright rays altered, two of them seeming to almost coalesce. In about ten minutes' time one ray turned approximately through $90^{\circ}$, and a new ray brighter than the other appeared on the right. The altitude of a ray when vertical was from $30^{\circ}$ to $40^{\circ}, 1$ should say. By 5.15 the rays became very faint and soon vanished, though above the dark bank of cloud I could detect a faint crimson-lake glow.

The day had been fine on the whole, except that there had been a little rain early in the morning, and a very heavy rain shower between I2 30 and I o'clock. The air was extremely clear, and the wind was blowing freshly from the west, or perhaps it was a bit north of west. It was blowing slightly from right to left across the line joining me to the sun.

This phenomenon of the pink rays revolving seems to be explaired by the dark spaces being due to clouds which were being hurried along by the strong west wind. I should like to know if any one living in a line W.S.W. of Cambridge noticed broken masses of cumulus clonds this afternoon oun head between 5.0 and 5.15 p.m. Greenwich time.

Caius College, Cambridge, October 26

\section{A Tertiary Rainbow}

THE supposed tertiary rainbow about which I sent a note a month ago must have been a halo formed by ice crystals, as readers of NATURE will perhaps have inferred merely from the recorded distinctness of the colours. It did not occur to me that ice crystals would be found in a horizontal direction from here, over the hot plains of the Punjab on the evening of an August day. But $I$ have since calculated the size of the tertiary rainbow and the order of colours in it, and the calculation leaves no doubt that the phenomenon must have been a solar halo, caused perhaps by a hailstorm over the plains.

Thaudiani, Punjab, Sept. 25

\section{T. C. LEWIS}

\section{The Sense of Colour}

In the early English "Lay of Havelok the Dane" the following words occur :-

" Also he wolde with hen leyke

That weren for hunger grene and bleike."

Mr. Allan Cunningham in his interesting paper (p. 604) does not allude to this old use of the word green. Is it a solitary case?

Belvedere, October 24

\section{Stone Axes, Perak}

A Curious Malay superstition has come to my knowledge concerning these implements. They appear to be very rare out here, and those found are treasured by Malays as lucky things to have about the house. I have as yet only been able to procure two specimens. One of these I have described in a paper on the Sakaies read before the Anthropological Society in June last. This nearly resembles Fig. 55 in Dr. Evans' "ancient Stone Implements of Great Britain," and is made of a soft description of slate which can be scratched with the thumb-nail. The other is of a much harder description of slate almost like greenstone ; it much resembles Fig. 76 of the same work. It is $7 \frac{3}{4}$ inches long, $I \frac{7}{8}$ inches wide at the widest end, which is sharpened, and I $1 \frac{1}{2}$ inches wide at the other end, which is not sharpened. The faces are flatter than those figured by Dr. Evans and the sides perfectly squared. It is beautifully polished, but several depressions are left all uver it, showirg that it had originally been chipped out. The Malays call them Bâtu-lintarh-i.e. thunderstones-and account for their fresence by saying that they are the missiles used by angels and demons in their continual warfare.

But the peculiarity of the superstition is this : the Malays aver that the soft implement which $I$ have described has been made by an angel or a demon and buried in the earth to become hard and fit for use, and support their argument by saying that these objects have been found freshly made of clay and quite soft, buried in the earth, where they have lately been deposited by some angel or demon for a future time of battle. The Malays say that the bâtu-lintarh is hard to procure in this state, as it almost invariably drops to pieces. For this reason they do not value it much, and more particularly because it has never inflicted a wound. The hard polished celt which I have just described, however, they value very highly, because they say it has been used in the aërial warfare and has inflicted a wound on one or more of the combatants. They adduce this supposition from the fact of the several depressions left by the chipping out of the implement, ard say that these marks were caused by its contact with the body of one of the demon comlatants. This la $t$ idea is very closely connected with another Malay belief, and most probably took its rise from it. This belief is that if the blade of a kriss or spear is bent or in any way damaged, it has most certainly wounded if not killed a man or some wild animal, and is therefore proportionately of much greater value. A Malay who professes to be a good judge of a kriss will, if asked to appraise the weapon, invariably first glance along the blade to see if it is bent ever so slightly, and if it is he will most certainly add two or three dollars to its value because it has "m'nikam orang" (struck a man). I have very little doubt that if some of the fine limestone caves of this district were thoroughly examined, they would yield a rich harvest of anthropological material.

Batu Gaja, Kiuta, Perak, September 6

\section{Photographic Action on Ebonite}

AT the back of one of the cases of lecture apparatus facing a north window in this laboratory, there happens to have been standing for six months or more an ebonite plate with a framed glass plate in front of it, the glass having a star.pattern done in little spots of tinfoil all over it. The thickness of the 